\title{
Antarctic glacial history from numerical models and continental margin sediments
}

\author{
Peter F. Barker ${ }^{\mathrm{a}, *}$, Peter J. Barrett ${ }^{\mathrm{b}}$, Alan K. Cooper ${ }^{\mathrm{c}}$, Philippe Huybrechts ${ }^{\mathrm{d}}$ \\ ${ }^{a}$ British Antarctic Survey, Madingley Road, Cambridge CB3 OET, UK \\ ${ }^{b}$ School of Earth Sciences, Victoria University of Wellington, P.O. Box 600, Wellington, New Zealand \\ ${ }^{c}$ U.S. Geological Survey, MS 999, 345 Middlefield Road, Menlo Park, CA 94025, USA \\ ${ }^{d}$ Geografisch Instituut, Vrije Universiteit Brussel, B-1050 Brussels, Belgium \\ Received 10 February 1998; accepted 16 November 1998
}

\begin{abstract}
The climate record of glacially transported sediments in prograded wedges around the Antarctic outer continental shelf, and their derivatives in continental rise drifts, may be combined to produce an Antarctic ice sheet history, using numerical models of ice sheet response to temperature and sea-level change. Examination of published models suggests several preliminary conclusions about ice sheet history. The ice sheet's present high sensitivity to sea-level change at short (orbital) periods was developed gradually as its size increased, replacing a declining sensitivity to temperature. Models suggest that the ice sheet grew abruptly to $40 \%$ (or possibly more) of its present size at the Eocene-Oligocene boundary, mainly as a result of its own temperature sensitivity. A large but more gradual middle Miocene change was externally driven, probably by development of the Antarctic Circumpolar Current (ACC) and Polar Front, provided that a few million years' delay can be explained. The Oligocene ice sheet varied considerably in size and areal extent, but the late Miocene ice sheet was more stable, though significantly warmer than today's. This difference probably relates to the confining effect of the Antarctic continental margin. Present-day numerical models of ice sheet development are sufficient to guide current sampling plans, but sea-ice formation, polar wander, basal topography and ice streaming can be identified as factors meriting additional modelling effort in the future. (C) 1999 Elsevier Science B.V. All rights reserved.
\end{abstract}

Keywords: Antarctic ice sheet; numerical models; glacial sediments; continental margin; stable isotopes

\section{Introduction}

The Antarctic ice sheet is today a major feature of the earth, occupying an area of 13.6 million $\mathrm{km}^{2}$ (Fig. 1) and averaging over $2 \mathrm{~km}$ in thickness. It contains a volume of fresh water equivalent to $4 \%$ of the modern ocean, about $66 \mathrm{~m}$ of sea-level change or a change in mean oceanic oxygen isotopic composition

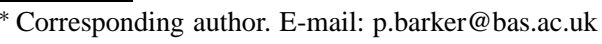

of $0.9 \mathrm{ppm}$. The Antarctic ice sheet is an important component of the global climate system, acting in several ways. It affects all aspects of regional atmospheric circulation, including sea-ice formation. Thence, and through cooling beneath ice shelves, it forms the cold, dense bottom water that helps drive ocean circulation. It controls high-latitude albedo directly, and affects low-latitude albedo indirectly by controlling global eustatic sea-level change. It affects seawater isotopic composition and, through ocean temperature 


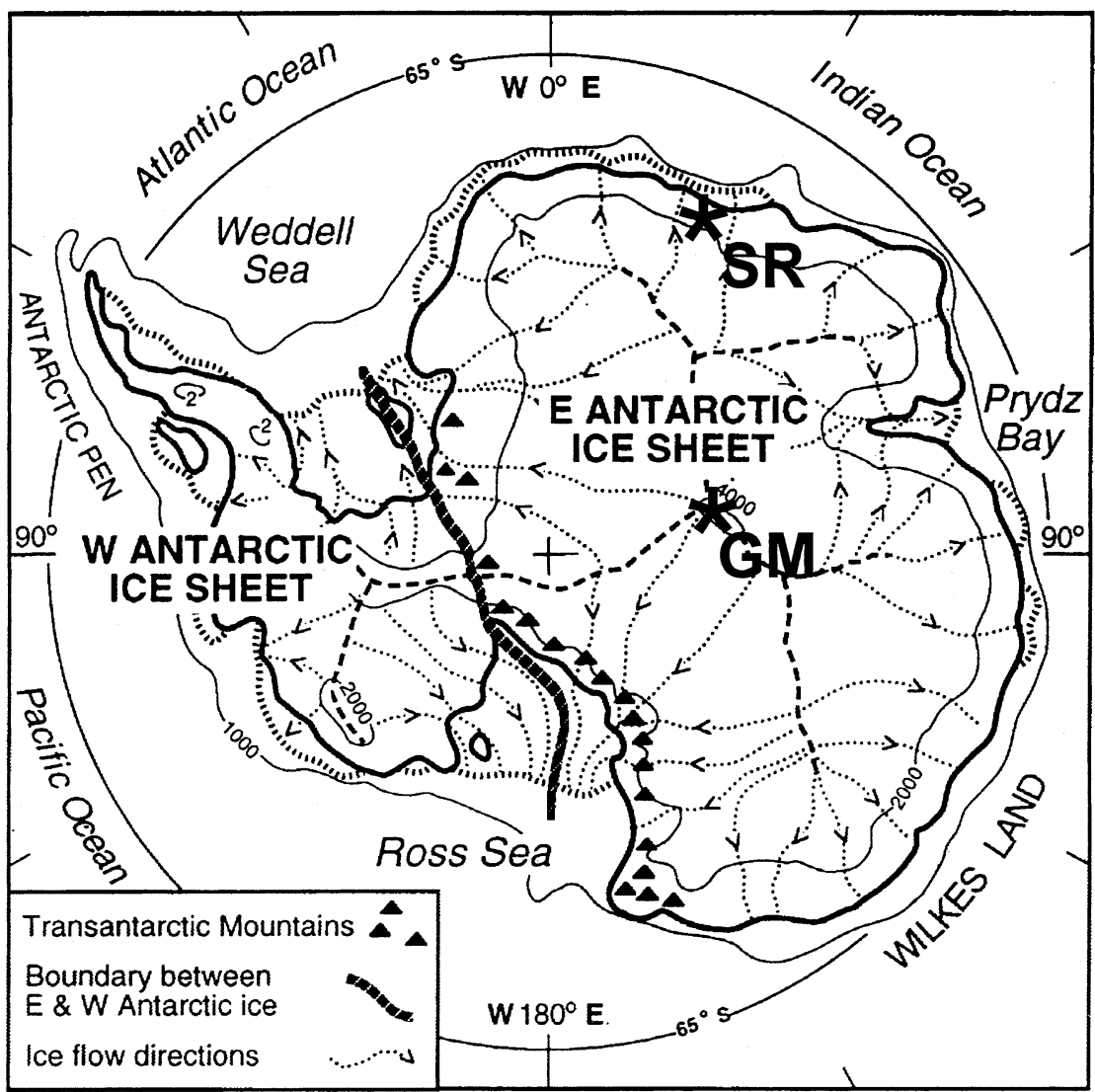

Fig. 1. The modern Antarctic ice sheet showing simplified ice drainage (NOT ice stream locations; see text) and thickness (after Drewry, 1983). The East Antarctic ice sheet is larger and considered more stable than the West Antarctic ice sheet. From Barrett (1996). GM= Gamburtsev Mountains; $S R=$ S $\varnothing r$ Rondane.

and circulation, influences biological production and the preservation of microfossils: it is therefore a major influence on sedimentation worldwide.

Ice sheet history is poorly known. The main evidence is from low-latitude proxies, where ice sheet volume is estimated from measurements of the effects described above: principally, from oxygen isotopes and global eustatic sea level, to a lesser extent from deep-ocean circulation, biogenic sedimentation and the distribution of ice-rafted detritus. However, the main estimates (from oxygen isotopes and sea level) disagree, and the others are less useful. The direct onshore geological record of Antarctic glaciation is sparse, geographically restricted and difficult to date, and is capable of more than one interpretation. The offshore sedimentary record is thick and extensive, but only a few holes have been drilled.
Over the past few years, largely through ANTOSTRAT (the Antarctic Offshore Acoustic Stratigraphy initiative), seismic reflection studies have examined the wedges of glacially transported sediments that have built out the Antarctic continental margin at the termini of the main ice drainage systems. These sediments and their derivatives on the continental rise contain a direct and accessible record of Antarctic ice sheet history. In this paper we summarise the characteristics of glacial sediment accumulations, and show how they may be made to provide a high-resolution record of ice sheet history by an optimal programme of direct sampling, coordinated using a published numerical model of ice sheet development. The numerical model considers the sensitivity of the ice sheet to changing temperature and (over a glacial cycle) to sea-level change. We 
consider the model's limitations and the effects these might have on our use of it to combine observations from different sectors of the Antarctic margin. From the model results we speculate about the ice sheet response to orbital (Milankovich) variation at times in the past, and consider possible causes of ice sheet growth, and relations to the oxygen isotopic record.

\section{Antarctic ice sheet history: present knowledge}

The history of the Antarctic ice sheet has been inferred from low-latitude proxy data — principally from oxygen isotopic measurements on deep-ocean benthic foraminifera and from the record of eustatic sea-level change adduced from sediments on lowlatitude continental shelves (e.g. Miller et al., 1987; Haq et al., 1987; Fig. 2). However, these inferences are ambiguous, and in disagreement (e.g. Sahagian and Watts, 1991), which not only leaves the history unresolved but also limits the credibility and usefulness of both sets of proxy data. For example, there is ambiguity between sea temperature and ice volume as explanations for changing oxygen isotopic composition. As a result, it is disputed whether the principal increases in Antarctic ice volume, affec-

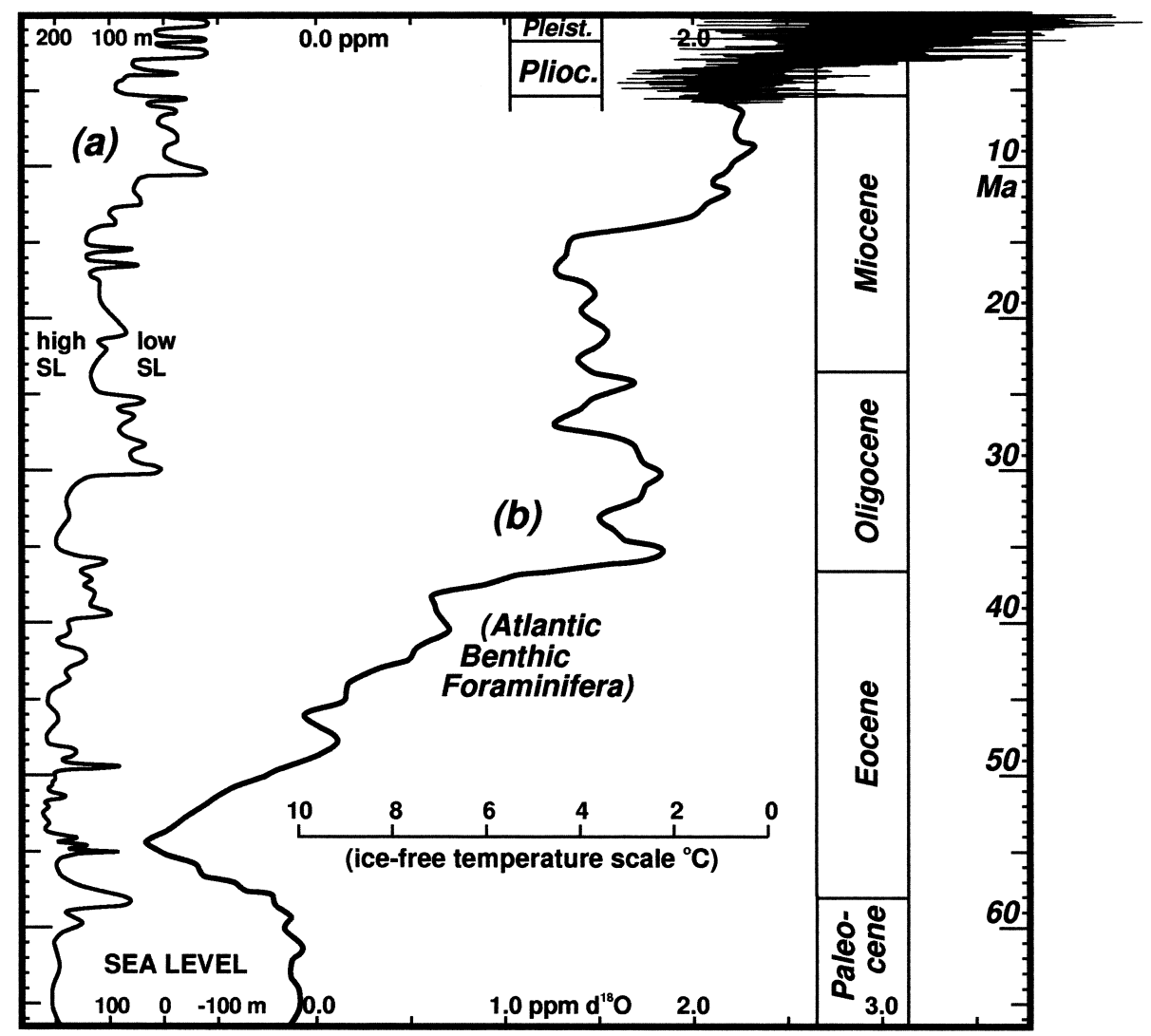

Fig. 2. A comparison of Cenozoic variation in proxies of ice sheet volume: (a) global eustatic sea-level from sequence stratigraphy (Haq et al., 1987); and (b) oxygen isotope ratios in Atlantic benthic foraminifera, with indication of water temperatures corresponding to an ice-free oceanic isotopic composition (Miller et al., 1987). Revised from Barker (1992) with high-resolution Plio-Pleistocene isotope record from ODP Site 659 (Tiedemann et al., 1994) superimposed to illustrate the limitations of the smooth isotope curve. Note that the older studies used time scales (Haq et al., 1988 and Berggren et al., 1985, respectively) similar to each other but significantly different from those (mainly, Cande and Kent, 1992; Berggren et al., 1995) used in subsequent work. 
ting the isotopic record, occurred at the EoceneOligocene boundary (about $36 \mathrm{Ma}$ in Fig. 2), at 16-13 Ma (middle Miocene) or only after about 3 $\mathrm{Ma}$, when major steps in the time-averaged curve are seen (Fig. 2b). Within this dispute, assumptions that may be incorrect have to be made about the constancy of equatorial surface temperatures (e.g. Matthews and Poore, 1980), or the high-latitude surface origins and temperatures of intermediate to deep waters at low latitudes. Also, there is much discussion over the stability of the ice sheet between times of major changes (see for example the considerable Oligocene isotopic variation in the smoothed curve of Fig. 2b, and Zachos et al., 1996). The existence of a superimposed isotopic variation at Milankovich periods (shown for the Plio-Pleistocene in Fig. 2 from ODP Site 659; Tiedemann et al., 1994) is generally acknowledged, but the amplitude and period of ice sheet variation are not completely defined by isotopic measurements.

Similarly, changes in grounded ice volume provide the only generally accepted repeatable, rapidacting cause for global eustatic sea-level change (Fig. 2a), yet the timing and amplitudes of sea-level change adduced from low-latitude continental margin sediments are disputed (e.g. Miall, 1991; Miller et al., 1996; Kominz et al., 1998), and changes occur also prior to late Eocene time (e.g. Browning et al., 1996) when there is no independent evidence for the existence of substantial volumes of grounded ice on Antarctica or elsewhere. Further, the isotopic and sea-level estimates of grounded ice volume disagree substantially with each other, at both long and short periods, through much of the Cenozoic (Fig. 2).

Other proxies are less useful. The 'psychrosphere' - cold deep and bottom waters generally considered to be maintained through interaction with Antarctic ice - originated at the Eocene-Oligocene boundary (Benson, 1975), but exactly what this means in terms of ice sheet volume is uncertain, and subsequent variation in bottom water production has not been examined. The first ice-rafted detritus (IRD) is seen in the late Oligocene on Maud Rise (Kennett and Barker, 1990), and early Oligocene on the Kerguelen Plateau and East Antarctic margin of the Weddell Sea (Wise et al., 1992). However, the abundance of IRD at a particular site is affected by ocean circulation and temperature, and the nature of continental glaciation, and bears no simple relationship to ice volume. For example, it is possible for an increase in IRD abundance at a site to accompany warming and deglaciation, through an increase in iceberg calving, a change from ice sheet to valley glaciers, or an increase in water temperature at the site. Clay mineralogy in circum-Antarctic sediments, reflecting the influence of onshore climate on weathering, has been used to argue the existence of low temperatures on East Antarctica in the middle or late Eocene, and extensive glaciation through the early Oligocene (Ehrmann and Mackensen, 1992).

The prospect for improved knowledge of ice sheet history from additional proxy measurement is limited. Some progress will be made by detailed isotopic analysis at very high resolution of carbonate sections from a large number of lower-latitude sites (e.g. Zachos et al., 1996, 1997). However, deep and intermediate waters of the Southern Ocean have generally been corrosive to the carbonate tests used almost exclusively in isotopic analysis, so benthic samples will be always from waters somewhat warmer than southern-origin bottom waters, and the problem of ambiguity between temperature and ice volume will persist.

Onshore Antarctic evidence of glacial history is sparse, and is also presently controversial: argument continues as to how stable the Antarctic ice sheet has been (e.g. Webb and Harwood, 1991; Denton et al., 1993; Stroeven et al., 1998; Harwood and Webb, 1998), based on observations onshore. Typically, striated surfaces, glacial erratics and thin diamicts with rare marine microfossils of disputed origin are found. Conflicting evidence comes from surface dating. Several hundred metres of glacial and ice-marginal strata have been found in the valleys of major East Antarctic outlet glaciers (e.g. Webb et al., 1996), but their ages are uncertain at present.

Antarctic continental shelf sediments have demonstrated glacial conditions in the early Oligocene or late Eocene on the Ross Sea shelf (Hayes et al., 1975; Barrett, 1989; Hannah, 1994) and in Prydz Bay (Barron et al., 1989), and over short periods subsequently. However, drilling in the past was based on limited seismic reflection data, imperfectly understood, and had mainly local targets of limited time extent. 


\section{Glacial sedimentation at the Antarctic margin}

Much progress has been made in recent years in collaborative interpretation of seismic reflection profiles from the Antarctic continental margin (particularly through ANTOSTRAT: see Cooper et al., 1994, 1995; Barker and Cooper, 1997). Together with the simplicity of the modern Antarctic glacial regime (compared with that of the Arctic), these activities led to the rapid emergence and application of a unifying model of glacial sediment transport and deposition (Alley et al., 1989; Larter and Barker, 1989; Bartek et al., 1991; Cooper et al., 1991a; Kuvaas and Kristoffersen, 1991).

Briefly, almost all ice transport to the ice sheet margins takes place within broad, rapidly moving ice streams. Rapid ice flow is enabled by low basal friction, the main source of which is basal melting and the presence of an overpressured and undercompacted, shearing basal layer of unsorted glacial debris (till). The necessary shear ensures that ice transport is accompanied by till transport, and virtually all of the transported till is melted out/dropped/deposited very close to the ice grounding line, where the ice stream becomes ice shelf before calving into icebergs and drifting north. The ice stream therefore essentially erodes and transports inshore of the grounding line, and deposits directly offshore, in an approximate high-latitude analogue of the low-latitude subaerial erosion/shoreline/marine sedimentation system (Fig. 3). Modern ice stream grounding lines are well inshore, but the grounding line advances and retreats under the influence of upstream ice provision and temperature, basal sediment supply and sea-level change: all related in some way to climate. Away from ice streams, ice sheet movement (and therefore associated sediment transport) is slow. Paterson (1994) estimates that ice streams drain $90 \%$ of total accumulation, but occupy only $13 \%$ of the ice sheet margin; recent satellite imagery (Showstack, 1997) shows even greater ice stream abundance.

The very large prograded wedges of ice-transported till beneath parts of the Antarctic outer continental shelf were deposited during a series of glacial cycles, within which the ice stream (indeed the entire ice sheet) was grounded to the continental shelf edge during many glacial maxima (Figs. 3 and 4). Deposition on shelf and slope is slow during interglacials,

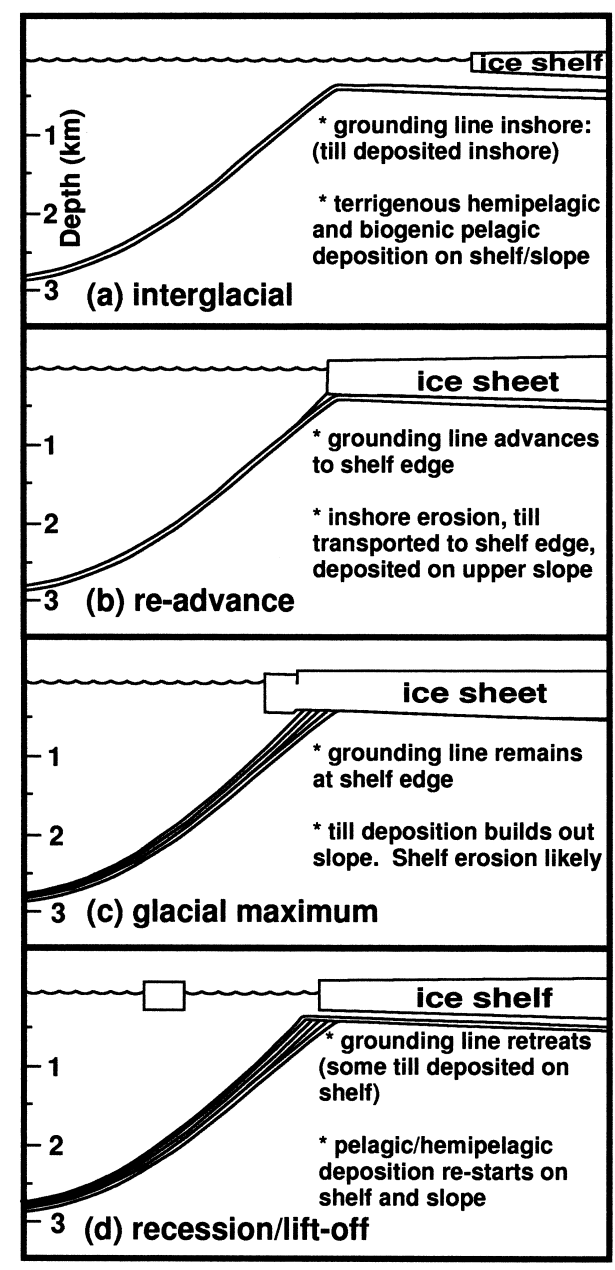

Fig. 3. Sequence model of deposition on shelf and slope through a glacial cycle (adapted from Larter and Barker, 1989, 1991). Unsorted till is deposited on the slope (foresets) during glacial maxima and on the shelf (topsets) during retreat. Pelagic or hemipelagic sediment is deposited on slope and rise during interglacials. With re-advance, some or all shelf topsets may be eroded.

and is mixed biogenic and terrigenous hemipelagic. Till is deposited on the shelf when an ice stream thins or when sea level rises, as during deglaciation, and erosion of shelf deposits can accompany glacial readvance. The glacial sedimentary regime has other characteristics. Progradation, and topset deposition on the shelf, are usually focussed into broad lobes or 'trough-mouth fans' opposite the ends of modern ice streams. Typically, fan and ice stream are connected by a topographic trough across the continental shelf. 


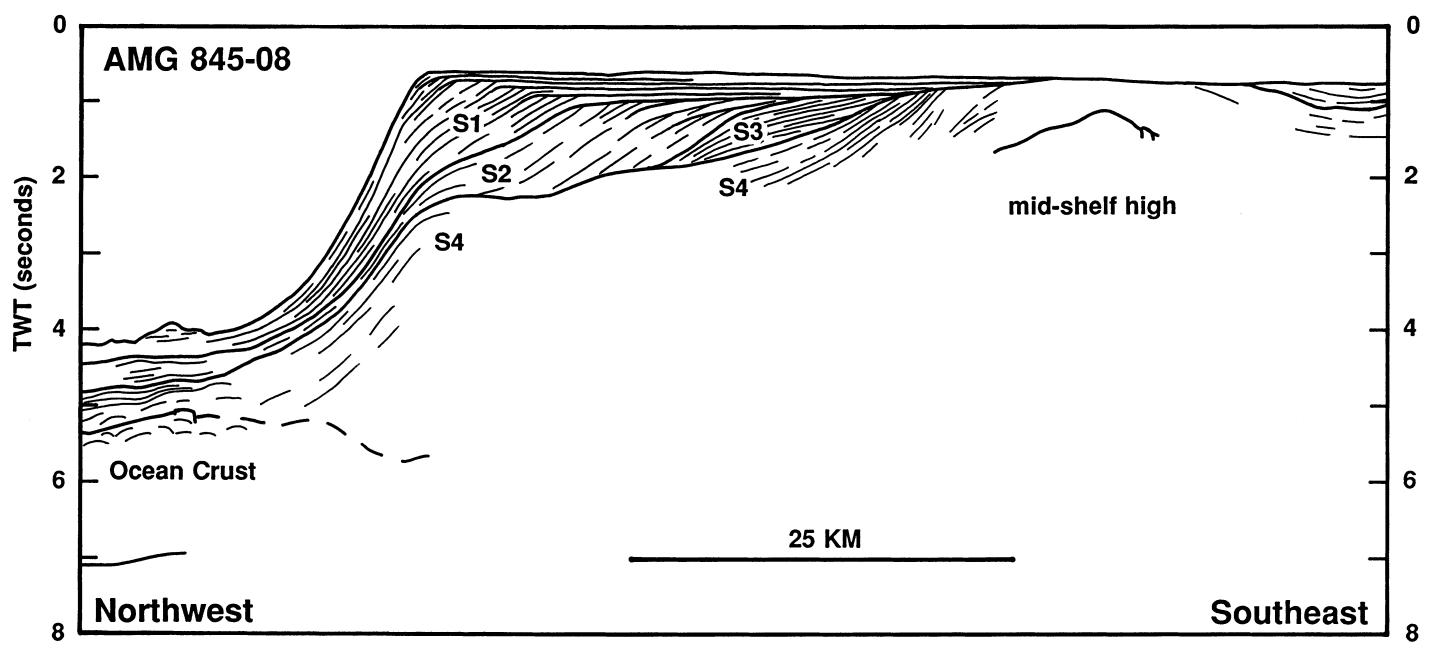

Fig. 4. Line drawing of MCS profile AMG845-08 from the Antarctic Peninsula margin, showing glacial sequence groups S1 and S2 overlying 'pre-glacial' sequence group S3, and S4 (Larter and Barker, 1989, 1991; Barker, 1995). S1 and S2 are built from glacial sequence units shown schematically in Fig. 3. ODP Leg 178 drilling confirmed S1 as glacial and partly late Pleistocene, S2 as glacial and partly early Pliocene, showed S3 to be also glacial, and sampled a conformable S3/S2 boundary at 4.6-4.5 Ma, but did not sample the conformable S2/S1 boundary. Drilling showed both the potential and the limitations of sampling the prograded wedge (Barker et al., 1999).

The ice streams and glacial troughs are broad (up to $80 \mathrm{~km}$ ) but trough-mouth fans are broader still, suggesting the lateral spreading of ice streams in regions of abundant basal till on the outer shelf, or lateral migration of ice streams with time (both within and between glacial cycles), or both.

The shelf is overdeepened by erosion (depth generally 300-600 m but in places much greater), and inward-sloping. Ten Brink and Cooper (1992) showed that only a minor component of this inward slope could be attributed to delayed isostatic response to removal of the ice sheet load, the major part being caused by erosion at the base of grounded ice, that thinned offshore in response to ablation and accelerating outward flow. Continental slopes are often steep, and in places turbidity current transport of the unstable component of upper slope deposition (with suspension within ambient bottom currents, and down-current deposition of fines) has produced large hemipelagic sediment drifts on the continental rise (e.g. Kuvaas and Leitchenkov, 1992; Rebesco et al., 1996, 1997; Escutia et al., 1997; Fig. 5). Provision of glacially transported sediment to the uppermost continental slope is highly cyclic — large quantities of unsorted till during glacial maxima, and very little during interglacials.
Three glacial depositional environments may be recognised: shelf topsets and slope foresets of the prograded wedge (Figs. 3 and 4), and proximal hemipelagic drifts on the continental rise (Fig. 5). Of these, the shelf record is potentially the least continuous. There, sediment is preserved mainly as a result of slow sea-bed subsidence, from cooling and compaction and from flexural lithospheric response to the topset and foreset load. Sediment is prone to re-erosion during the next glacial advance, so the topset record is discontinuous and relies on interbedded or intermixed interglacial biogenic sediments for dating. The more continuous foreset record is an essential complement. The proximal rise drifts are as yet only sparsely sampled, but potentially contain an excellent high-resolution record, closely related to that of the upper slope foresets from which they are derived. A prerequisite for a faithful, high-resolution glacial-interglacial record within the drifts is a short residence time for the unstable component of glacially transported sediment on the continental slope. Then, drift sedimentation would alternate between rapidly deposited, poorly fossiliferous terrigenous fine silts and clays during glacials, and slowly deposited pelagic biogenic muds (with only a minor terrigenous component) during interglacials. 


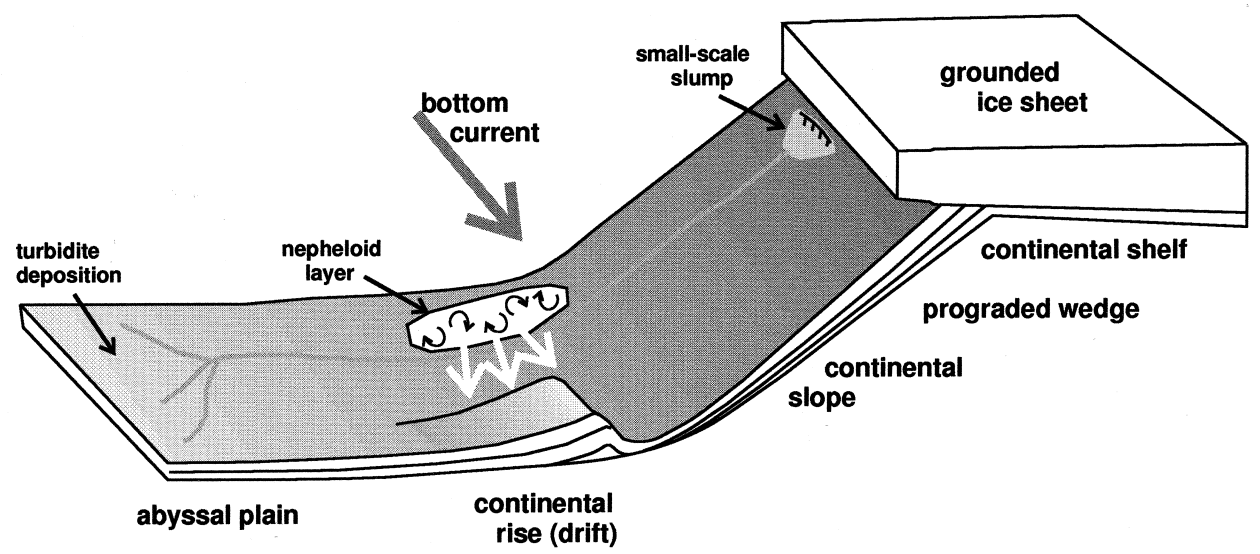

Fig. 5. Schematic drawing of processes active during glacial half-cycles, leading to development of hemipelagic sediment drifts on the continental rise (adapted from Rebesco et al., 1997). The unstable component of unsorted upper slope deposits forms a small-scale slump (leaving a headwall scarp on the upper slope) and debris flow, thence a turbidity current that transports sand and silt to the abyssal plain. The fine fraction from the turbidity current (cloud with curling arrows) is suspended and entrained in ambient bottom currents (white arrows), to be deposited down-current. Drifts are built above the level of the dendritic pattern of turbidity current channels on the continental rise and abyssal plain, because (in the case of the Antarctic Peninsula margin and perhaps elsewhere) subsequent turbidity currents erode the deposited sediment everywhere except upon the drifts, and maintain the steeper drift slopes at the limit of stability.

Older seismic data and existing drill sites from around Antarctica have demonstrated the coarse (but not as yet the fine-scale) climate record in continental rise sediments and the likely climatic sensitivity of continental margin wedge geometry (Barker, 1995), and revealed the partial nature of the shelf topset record (Hayes et al., 1975; Barron et al., 1989). About 200,000 km of multichannel seismic data have now been collected around the Antarctic continental margin (e.g. Cooper et al., 1995; Barker and Cooper, 1997), allowing the potential of these depositional environments to be more fully recognised.

\section{Regional and time variation}

There is considerable variation in the characteristics of catchment areas of individual ice streams, which the geometry of the prograded wedge is likely to reflect, as well as being sensitive to climate change. For example, the ice catchment of the Antarctic Peninsula is all proximal, within $200-300 \mathrm{~km}$ of the continental shelf edge: snowfall is high, but little is held in an ice sheet reservoir because of the narrowness of the high-elevation catchment (Drewry and Morris, 1992). The Antarctic Peninsula glacial regime is high-throughput, low-reservoir and proximal, most probably a rapid-response system capable of providing a high-resolution sedimentary record of externally driven change. In contrast, the eastern Ross Sea is itself an area of low precipitation (Giovinetto et al., 1990) and low relief. Its ice streams and associated tills are derived from a large, distal, low-elevation region (indeed, with a base below sea level) in the West Antarctic interior, up to $2000 \mathrm{~km}$ from the continental shelf edge. Although the West Antarctic ice sheet is itself most probably quite sensitive to change, because of its marine base (e.g. Bentley, 1984; Fastook, 1984), the geometry of the prograding sediment wedge in the eastern Ross Sea (e.g. Alonso et al., 1992) is different from that off the Antarctic Peninsula (Fig. 4), reflecting its different catchment characteristics. The Prydz Bay and Weddell Sea margin wedge geometries are different again (for discussion, see Barker, 1995), and most Wilkes Land sections (Eittreim et al., 1995) lack topsets altogether.

Despite these regional differences, major changes in prograded wedge geometry in a region reflect changes in climate with time. Wedge geometry would reflect the behaviour of the ice base, which is dependent on sea level but also on basal conditions (till supply) and ice flow rates (temperature, accumulation, change in catchment geometry). For a typical Antarctic margin, and steady cooling from an initial 
non-glacial state, the earliest source of ice may be distal - winter snow producing a small interior ice cap flowing to sea level (e.g. temperate glaciers, as in Iceland today). Continental margin deposition away from the glacier (/ice stream) is fluvial. Then, further cooling depresses the equilibrium line, increasing the ice catchment area (a local component is added, the proximal fluvial regime becoming glacial), until ice extends everywhere to sea level. Further cooling may then decrease flow, as ice becomes colder and thus harder, and the basal melting zone diminishes. This may reduce the till supply, thicken the ice stream and lower its base. Sea-level change would also affect the ice stream base. In a further complication, till supply would change systematically with time if a region of softer sediments overlying harder rocks were progressively eroded.

Seismic reflection profiles verify that the geometry of deposition within many prograded wedges has changed with time. In 2-dimensional terms (assuming that the seismic profile is representative, and any lateral variation has been determined), a range of depositional geometries may be mapped by following the locus of the palaeo-shelf edge; this may of course be obscured by subsequent topset erosion. For the Antarctic Peninsula outer shelf, for example, two glacial sequence groups were recognised (Larter and Barker, 1989, 1991; Fig. 4) above a 'pre-glacial' S3. S2 is apparently progradational, but its topsets have largely been planed off during the erosional event that ended it, and began the succeeding group S1. Within S1, progradation is less apparent, and several smaller instances of topset erosion may be seen. The eastern Ross Sea shelf shows a similar geometric change (e.g. fig. 3 of Alonso et al., 1992), but the dimensions of sedimentary units are very different: progradation is more extensive, and the slope less steep (effects, probably, of the different catchments). In Prydz Bay too, a similar mid-section erosional episode is widespread within the prograded wedge (Cooper et al., 1991b; Leitchenkov et al., 1994; Barker, 1995). These changes in wedge geometry reflect changes in climate, interacting with regional catchment characteristics. Their ages are almost certainly different from each other, but are unknown without direct sampling.

There are similar differences within drift bodies on the continental rise. Those off the Antarctic
Peninsula margin are close to the foot of the continental slope, yet detached from it by dissection caused by turbidity currents draining the slope. Deposition on the drifts is mainly from a nepheloid layer of the ambient bottom current, supplied from the entrained fines of successive turbidity currents (Rebesco et al., 1996, 1997; Camerlenghi et al., 1997). Direct turbidite deposition on the drifts is difficult, except at their lower-elevation, distal end. Off Prydz Bay, in contrast, a directly deposited distal turbidite component is probable, although the elevated form of the drifts reveals significant hemipelagic deposition also (Kuvaas and Leitchenkov, 1992). With continued operation of the glacial sediment transport regime at an Antarctic continental margin, a gradual change from a turbidite-dominated to a largely hemipelagic drift seems likely, as the drift becomes more elevated above its surroundings.

The contributions essential to drift formation are abundant sediment supply, and bottom current action. Fortunately, the bottom current influence on most drifts around Antarctica appears small: they lie far to the south of the vigorous Antarctic Circumpolar Current (ACC), and the west-flowing Antarctic coastal current is generally slow. The evidence from seismic reflection profiles is of steady deposition of fine-grained sediments with only minor bottom current control (Kuvaas and Leitchenkov, 1992; Rebesco et al., 1996, 1997; Escutia et al., 1997). A long record of climate change from the drift sediments seems likely.

ODP Leg 178 drilled the Antarctic Peninsula margin early in 1998. Core recovery was excellent on the sediment drifts, poor on the shelf prograded wedge. The high-resolution record within the drifts has not yet been fully examined, but preliminary results (Barker et al., 1999) verify the glacial nature of the shelf prograded wedge (including sequence group S3 of Fig. 4), and suggest the persistence of a glacialinterglacial cyclicity over the past $9 \mathrm{Ma}$ or so.

\section{Numerical models of the ice sheet}

In previous sections we have described sediments deposited under a glacial regime that are abundant around the Antarctic continental margin. They are well-mapped by seismic reflection methods in sev- 
eral sectors of the margin, and their mode of deposition is largely understood. They contain a record of grounded ice sheet extent that is accessible to direct sampling. To step beyond this, and extract from them a history of ice sheet evolution, as is proposed here, we need to be able to combine information from different sectors of the margin. Indeed, since the process of sampling margin sediments is itself difficult and expensive, we need to determine how little sampling is required to obtain this history, and where the best sampling sites will be.

Data from different sectors of the margin may be combined by means of numerical models of ice sheet evolution. As computing power has grown, numerical models have become increasingly realistic, and therefore (without compromising the integrity of their approach) increasingly acceptable and useful to the lay community. A recent model by Huybrechts (1990, 1992, 1993) examined both the development of an Antarctic ice sheet with progressive longterm cooling at the continental margin and (in a different model run) the response to sea level and temperature change through the last glacial cycle. The model had a 40-km grid size and 10 vertical layers, and included a realistic temperature-dependent precipitation scheme and ice rheology, sub-ice topography and isostatic response. It did not include ice streaming on a till base, but allowed basal sliding under conditions of pressure melting, as an arbitrary function of shear stress and load (which is roughly equivalent).

The long-term model is illustrated in Fig. 6 (from figs. 6 and 9 of Huybrechts, 1993). That particular model run is forced by a constant offset from an empirically determined mean annual temperature around the Antarctic margin (Giovinetto et al., 1990; Huybrechts, 1993, p. 226). Ice sheet volume reduces as the mean annual temperature is raised above modern values, hardly at all at first but then progressively more quickly as temperature increases (Fig. 6a). The direction in which the model is run is unimportant except for two short sections centred on about $+9 \mathrm{~K}$ and $+19 \mathrm{~K}$. The model ice sheet responds to rapid temperature change in times of the order of 10,000 40,000 years (for cooling) and 3000-4000 years (for warming), suggesting that the ice sheet would have responded quickly to the major climate changes seen in the geologic record.
Fig. 6b shows the geographic disposition of the ice sheet as its volume changed. Assuming a steady cooling, leading to a steady ice sheet growth, the small, early ice sheet would have occupied the continental interior of East Antarctica, initially around the Gamburtsev Mountains but with lesser nuclei on the Sør Rondane and southern Transantarctic Mountains (see also Fig. 1). Subsequent development from these nuclei meant that the bias of ice volume at intermediate temperatures was towards the Atlantic, with the SE Indian Ocean sector developing later, followed by West Antarctica and the Antarctic Peninsula.

In general terms, therefore, the model suggests that the earliest glacial sedimentation at the Antarctic continental margin may have been in Prydz Bay (from a glacier flowing via the Lambert Graben) and in the eastern Weddell and western Ross Sea embayments (subsequently re-eroded perhaps). Then, progressively, off Wilkes Land (with an increase in Prydz Bay transport accompanying the development of a local ice sheet), then the eastern Ross Sea and western Weddell Sea (from West Antarctica) and the Antarctic Peninsula.

It seems reasonable to suppose that continental margin sedimentation is most sensitive to climate change as the ice sheet first arrives. The margin then continues to accumulate glacial sediments as the temperature drops lower, but becomes less sensitive to change. From the numerical model, it is possible to suggest which stages of the overall development of the ice sheet might be reflected in the onset of glacial sedimentation at different parts of the Antarctic margin. We may then try to ensure that all sections of the simple growth curve of Fig. 6a are covered, by sampling one sector of the margin or another at the time when it is most sensitive to climate change. By sampling margin sediments, that stage of ice sheet development can be assigned an age. In several parts of the Antarctic margin, sufficient seismic reflection profiles exist to allow glacial sediments to be mapped. In Fig. 7 we suggest the ice sheet size ranges for which each of these parts of the Antarctic margin might be most sensitive. The initial stage of ice sheet growth, to perhaps $30 \%$ of present-day volume, would involve grounding line advance to Prydz Bay and the eastern Weddell Sea. Growth from about 50\% to perhaps $80 \%$ would involve advance to the Wilkes Land margin, accompanied by a distinct change (to a proximal 

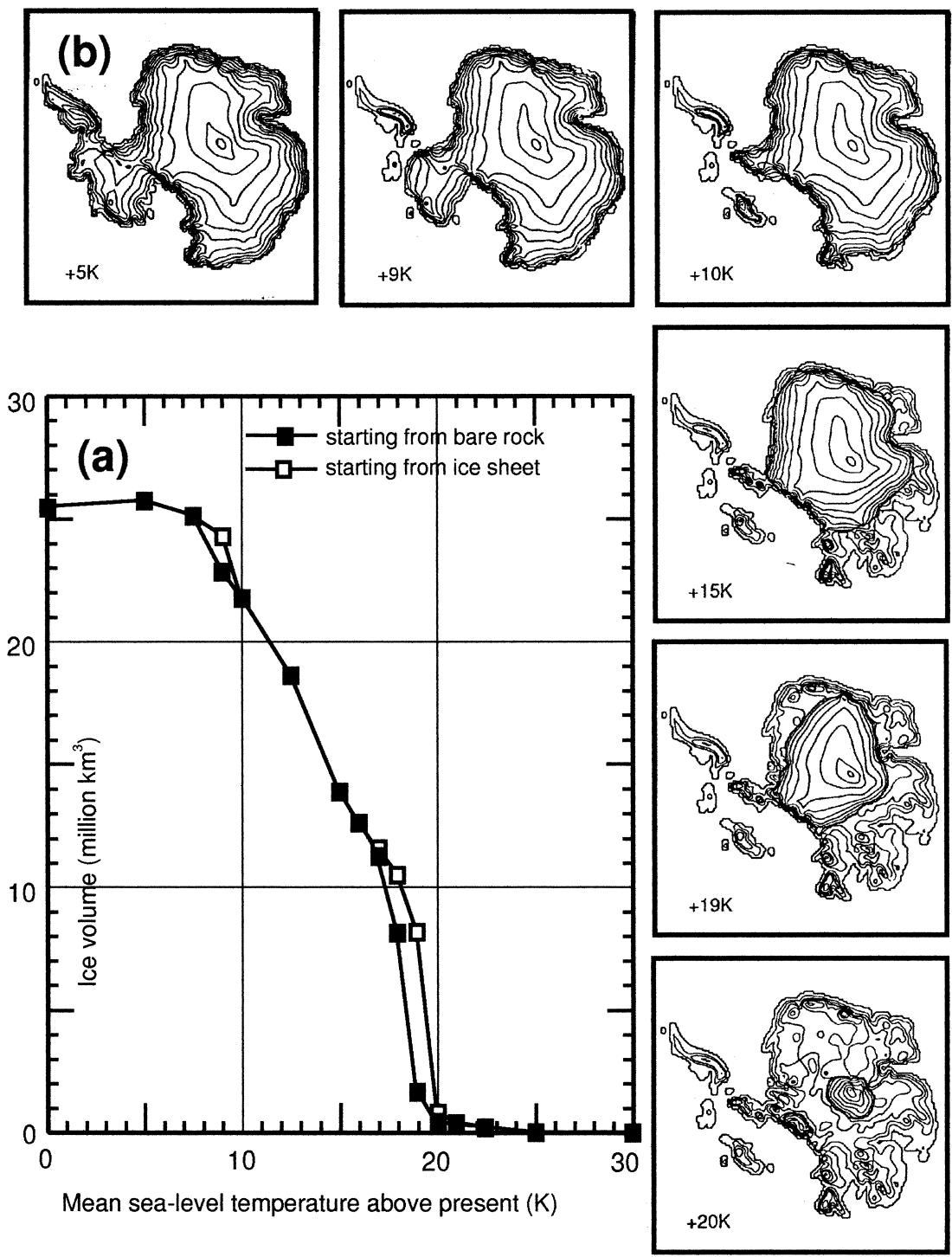

Fig. 6. (a) The dependence of ice sheet volume upon mean annual temperature at sea level around the coastline, above that of today (K). (b) The geographic distribution of an ice sheet stable at each of a series of mean annual temperatures $(5,9,10,15,19$, 20 K) above today's. From Huybrechts (1993).

ice regime) in Prydz Bay and then a sensitivity to initial West Antarctic ice sheet development in the eastern Ross Sea. The Antarctic Peninsula record extends across the near-constant-volume phase of ice sheet development, where cooling may be reflected in reduced ice sheet energy (less snow accumulated, balanced by colder, slower ice stream flow) and thus reduced sediment transport.
This is the basic ANTOSTRAT sampling strategy. The five regions of the continental margin mentioned have all been adequately surveyed. All sections of the ice sheet growth curve can be dated by sampling at three or four of these regions (Fig. 7). The Ocean Drilling Program drilled off the Antarctic Peninsula margin early in 1998 as a test of viability of the strategy (above), and is considering proposals for 


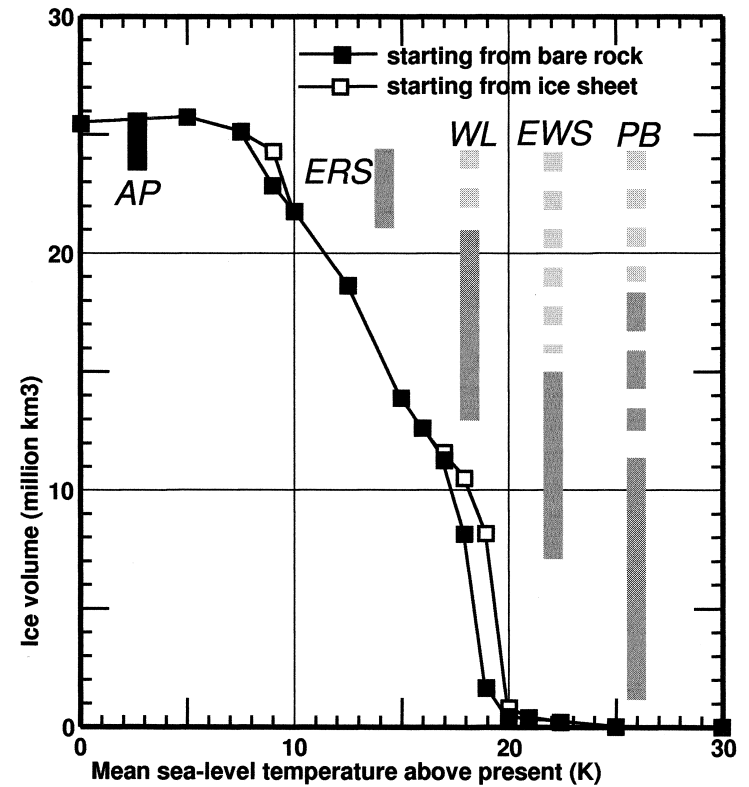

Fig. 7. The ice sheet growth curve of Fig. 6a, with the sensitivity of particular regions of the continental margin marked. A solid line (dark grey) notes the range of ice sheet volume within which sedimentation at the continental margin will be particularly sensitive to ice margin position. A dotted line (light grey) shows a continental margin that is glaciated but probably less sensitive. $E W S=$ eastern Weddell Sea; $P B=$ Prydz Bay (with possibly two sensitive stages); $W L=$ Wilkes Land; $E R S=$ eastern Ross Sea; $A P=$ Antarctic Peninsula (line shown black because drilling has taken place).

subsequent drilling in Prydz Bay, off the Wilkes land margin, and in the eastern Ross and Weddell seas. Sampling would focus on the earliest stages of glaciation at a margin, and on changes in margin wedge geometry.

\section{Assumptions of the ice sheet model}

While the ice sheet model by Huybrechts (1990, 1992, 1993) appears sufficiently detailed and robust for present purposes, there are qualifications to the model assumptions, that urge further caution. The five main ones are described below.

\subsection{Mean annual temperature at sea level}

At first sight, the strategy of starting with a regression fit to the present-day mean annual sea-level temperature around the continental margin, then increasing it evenly, is attractive; it allows to first order for the differences in latitude and proximal elevation, and ocean currents, at different points around the margin. However, the effects of sea-ice formation on mean sea-level temperature may be particularly great, so that at times when sea ice may be forming seasonally at some points around the margin but not at others, the assumption of uniform temperature increase may be unreasonable. The presence of sea ice increases albedo and inhibits heat exchange between ocean and atmosphere (see King and Turner, 1997), leading to a cooler and dryer atmosphere. This is a kind of positive feedback on a regional scale the colder parts of the margin become colder still, compared with the warmer parts. It suggests that proportionately greater cooling accompanied an earlier onset to sea-ice formation in the more southerly parts of the margin (Weddell and Ross Sea embayments). Also, regional differences in temperature at sea level around Antarctica may have been greater before inception of the ACC, and less clearly related to present conditions when the ice sheet was small.

\subsection{Accumulation}

The model assumes that precipitation is linked to mean annual surface temperature, changing only with elevation and position. While this assumption appears valid for the present Antarctic and Greenland ice sheets, and reproduces the mass balance of all the Northern Hemisphere ice sheets through modern glacial cycles (Huybrechts and T'siobbel, 1997), it should be viewed more cautiously. Precipitation patterns depend also on such factors as cyclonic activity, distance from a moisture source and orientation of the surface with respect to prevailing winds (cf. Fortuin and Oerlemans, 1990; Giovinetto et al., 1990). GCM studies of Antarctic climate, that might throw light on such matters, are few, but work by Oglesby $(1989,1991)$ suggests that, if anything, a milder Cenozoic climate at the Antarctic margin would have been accompanied by a cold Antarctic interior and a greater precipitation than predicted by Huybrechts' (1993) parameterisation. 


\subsection{Polar wander}

The first-order correction for latitude, incorporated in the temperature forcing (Huybrechts, 1993, above) also becomes unrealistic in the face of changing palaeolatitude (particularly for the period before the onset of circum-polar current flow). Polar wander curves (e.g. fig. 15 of DiVenere et al., 1994) show a south geographic pole sweeping through a $20^{\circ}$ arc within the South Atlantic sector of East Antarctica over the past 50 million years, suggesting that the eastern Weddell Sea would have been colder initially than the simplest assumptions might suggest, and the Wilkes Land and Ross Sea margins warmer.

\subsection{Basal topography}

Over 35 million years, erosional lowering of the continental interior (only partly compensated isostatically) and progradation of the margin would make an ice sheet steadily more difficult to develop (Barker, 1992), but little is known of the age and tectonic evolution of some elevated areas (e.g. Gamburtsev Mts) that would have influenced ice sheet growth. Fission track data imply $7 \mathrm{~km}$ or more rift-shoulder uplift of the Transantarctic Mountains (TAM) over the last 50-55 million years (Fitzgerald, 1992, 1994), with compensating (but unevenly distributed) erosion. Huybrechts' (1993) main model run assumed no erosional or depositional modification of basal topography (present-day sub-ice topography, isostatically adjusted), but he showed also that use of a model continent with the TAM and other sub-ice topography significantly lowered, would not change the general dependence of ice sheet growth on temperature in a major way. Locally, topographic changes would have been important, and could inhibit the incorporation of data (for example, from the western Ross Sea because of the TAM) into a continent-wide synthesis.

\subsection{Ice streams}

The ice sheet model is 'classical' in the sense of assuming that the basal boundary conditions that govern ice flow are solely a function of basal temperature and pressure. Transport in ice streams on a low-friction bed of deforming till (which, of course, provides
ANTOSTRAT's recording medium) is not included. It is not clear if the model's classical assumptions of ice flow with basal melting simulate ice stream flow completely. If not, then the model ice sheet probably has a slower response to climate change than the real ice sheet. However, model response times are sufficiently fast to react to the time scales of climate change that we consider here, even without ice streaming. In the longer term, it seems likely that sub-ice geology will have governed ice stream location, by controlling the availability of easily erodible material. The geology would therefore have controlled the pattern of subglacial erosion (see Bell et al., 1998), and evolution of sub-ice topography. An additional effect of till-mediated ice flow would be to transport ice within glaciers for a distance beyond the main ice mass, leading to an earlier indication of glacial erosion there than the overall ice volume would suggest. An example might be flow along the Lambert Graben into Prydz Bay from a small interior ice sheet nucleated on the Gamburtsev Mts.

It is important to stress here that the objective of sampling continental margin sediments is not to test hypotheses of absolute sea-level temperature, but to determine the history of ice sheet development. In essence the Huybrechts (1990, 1992, 1993) model ice sheet appears robust to minor changes in basal topography, which may change the temperature scale but not the essential shape of the curve. The other effects noted above (sea-ice cover, polar wander, till transport) seem likely to be minor also, and important primarily when comparing regions in detail. The basic shape of the curve is of steady change in ice sheet volume, with rapid initial growth, then slower growth, then, over the last few degrees of cooling, virtually no growth at all. We suggest there are implications in this shape for the causes of growth. However, before examining these we should consider the glacial cycle, which may be seen as a short-term variation superimposed on long-term development.

\section{The glacial cycle in ice sheet history}

Through the late Pleistocene, glacial cycles have had a dominant period of about 100,000 years and an amplitude of 1.7 to $1.9 \mathrm{ppm}$ in oxygen isotopic variation in deep-water benthic microfossils and up to 120 
$m$ in sea-level change. It is generally considered that by far the greater part of these effects is the result of growth and decay of vast Northern Hemisphere ice sheets (e.g. Broecker and Peng, 1982; Schrag et al., 1997), and that the past 3 million years have seen these effects grow, from an initial isotopic signal amplitude of 0.4 to $0.6 \mathrm{ppm}$ and sea-level change of perhaps $25 \mathrm{~m}$, with a dominant period close to 40,000 years. It seems likely that change in volume of the Antarctic ice sheet itself was the major cause of these lower-amplitude and shorter-period changes before 3 million years, but the relative importance of ice volume and ocean temperature contributions to the isotopic variation is unknown. Data are sparse; from lower latitudes, high-resolution isotopic data have been acquired that extend back to the late Miocene (Tiedemann et al., 1994; Shackleton et al., 1995) and sample isolated earlier times (Pisias et al., 1985; Zachos et al., 1996, 1997), but their interpretation in ice volume terms remains ambiguous: the global validity of high-resolution sea-level change data is difficult to establish.

As yet no high-resolution data are fully available from Antarctic margin sampling, but it is useful here to consider the likely consequences of externally imposed (Milankovich, insolation) changes on a developing ice sheet. Huybrechts $(1990,1992)$ investigated the response of the modern Antarctic ice sheet to the last glacial cycle, but there is no direct insight from modelling as to how a warmer, smaller ice sheet might have behaved.

Huybrechts concluded that the major effect on ice sheet volume through a modern glacial cycle was from the large change in sea level. Lowered sea level (almost entirely from changes in Northern Hemisphere ice volume) caused grounding line advance, mostly to the continental shelf edge. In the sense that sea-level lowering resulted from cooling, and caused ice volume increase and thus additional sealevel lowering, it may be seen as providing positive feedback.

The nett thermal effect on Antarctic ice sheet volume in Huybrechts' model of the glacial cycle was small: a lower temperature reduces precipitation, but also reduces basal melting and creates stronger ice, reducing rates of flow. The small nett effect on volume is compatible with the sub-horizontal slope of the colder part of the volume-temperature curve in Fig. 6a, and the reduced late Pleistocene ice flow is supported by observation of reduced rates of accumulation of terrigenous sediment around Antarctica (Barker, 1995). The time lag in model ice sheet response to climate change was generally short $(10,000-20,000$ years except for basal temperature), and the ice sheet appeared capable of approaching (but not reaching) equilibrium through a modern glacial cycle. Different regions of the continental shelf saw slightly different lag effects, particularly the Ross and Weddell Sea embayments. However, the existence of ice streams (not modelled) may serve to reduce both the overall time lag and these regional differences.

The observed and modelled effects of the modern glacial-interglacial variation cannot be assumed to have applied in the past. Although orbitally induced changes in insolation have persisted through the Cenozoic, several differences from the modern earth system response must be considered.

(a) The present amplitude of sea-level change, the result of Northern Hemisphere ice volume change, is too great. Neither Fennoscandian nor Laurentian ice sheet is likely to have existed before 2.5 to $3 \mathrm{Ma}(\mathrm{N}$ Atlantic ice-rafting as old as $14 \mathrm{Ma}$ does not indicate large ice sheets: Thiede and Myhre, 1996). The dominance of sea-level change over other influences on ice volume will have been less before 2.5 Ma. Indeed there is a question over the existence of a significant ice sheet effect at all, since the Antarctic ice sheet, acting alone, would have had to provide its own sea-level change. If it was only slightly warmer than today's, the early Pliocene-late Miocene ice sheet may have remained in the flat, upper region of the temperature-volume curve (Fig. 6a) where temperature sensitivity is small. Isotopic data show the persistence of a 40,000 years signal, with a lag which has been suggested to result from the existence of a Milankovich-sensitive ice sheet, back to at least 4 Ma (Shackleton et al., 1995). However, it is not clear quite how orbital insolation variations would have driven the ice sheet in these circumstances, and a weak response seems likely. The lag is not seen between 5 and $6 \mathrm{Ma}$.

(b) At warmer temperatures (warmer than $9 \mathrm{~K}$ in Fig. 6a) there is a clear dependence of model ice volume on temperature $(1 \mathrm{~K}$ cooling produces 1.5 million $\mathrm{km}^{3}$ ice sheet growth, about $4 \mathrm{~m}$ sea-level fall). In this case, glacial-interglacial temperature 
change would have driven ice sheet volume. For this section of the curve, however, Fig. $6 \mathrm{~b}$ shows that the ice sheet does not reach the continental margin all around West Antarctica, so the effectiveness of sea-level change as a positive feedback mechanism is reduced. At warmer temperatures still, the temperature-volume curve steepens, so the Milankovich temperature effect is more prominent, but the feedback effect of sea-level change is reduced further, as the ice sheet extends to sea level in progressively fewer places.

(c) Thus, a major contributor to the sub-horizontal slope of the colder part of the ice sheet-temperature curve may have been the limited size of the continent. Once the ice sheet had reached the margin around the continent, and occupied the continental shelf during times of lowered sea level, it is hard to see how volume could have increased significantly. Lower ice temperatures limit basal melting (hence flow, including till-mediated flow), but also reduce precipitation. The steeper slopes of the ice volume-temperature curve in Fig. 6a may reflect mainly the freedom available for an ice sheet to expand and contract in response to (Milankovich-driven or other) temperature change, largely unimpeded by arrival at a continental margin. In its earliest stage of growth, the Antarctic ice sheet may have behaved like the Northern Hemisphere ice sheets have done most recently, undergoing large latitudinal changes in the onshore position of the ice margin through a glacial cycle.

In summary, we may expect Antarctic ice sheet volume to have been sensitive to Milankovich orbital variation throughout its history. The period when this sensitivity was least certain would have occurred more recently (in the early Pliocene-late Miocene, for example), if the Antarctic ice sheet was within the sub-horizontal part of the long-term temperature curve before Northern Hemisphere glaciation developed. At warmer temperatures, the thermal effect would have been the greater, and the sensitivity to sea-level change weak or absent.

\section{Timing and causes of ice sheet growth}

Some aspects of the curve of temperature-dependence of model ice sheet volume have already been considered. We have suggested that, in essence, the change with decreasing temperature from a steep slope to a more gentle slope, and then to the subhorizontal, reflects the progressive arrival of the ice sheet edge at the continental margin. The first change, at about $18 \mathrm{~K}$ in Fig. 6, appears to coincide with the arrival of the East Antarctic ice sheet at the Weddell Sea margin, and the second, at about $9 \mathrm{~K}$, occurs once a nucleus of the West Antarctic ice sheet has developed. Also, the form of the superimposed glacial-interglacial variation has been discussed: there are no useful data against which to test this hypothesis as yet, but some form of superimposed short-period variation is indicated by isotopic data. One important effect of this superimposed variation was probably to make the initial indication of ice sheet extension to the continental shelf edge (an event detectable by sampling the glacial margin prograded wedge) occur earlier than the 'mean' or 'interglacial' model of Fig. 6 would suggest.

Other interesting consequences of the shape of the curve in Fig. 6a emerge, if it is compared with curves of long-term oxygen isotopic change such as that in Fig. 2b (Miller et al., 1987). In such a comparison, the isotopic curve should itself be used with care. It was produced by combining data from many different sites, which required application of a smoothing filter, to acknowledge the limitations of stratigraphic correlation and to average out an aliased glacial-interglacial variation and the scatter of palaeotemperatures at a range of seabed sites. The 'average' is not perfect, however, and much of the ambiguity between ice volume and water temperature remains. Nevertheless, certain features of this curve are of great interest.

In particular, the isotopic curve of Fig. 2b shows three large discontinuities: (a) at the EoceneOligocene boundary at about $36 \mathrm{Ma}$ (timescale of Berggren et al., 1985); (b) in the middle Miocene at $16-13 \mathrm{Ma}$; and (c) at about $3 \mathrm{Ma}$ in the midPliocene. The first has been shown by more detailed studies of single-site core sections (e.g. DiesterHaas and Zahn, 1996; Zachos et al., 1996) to have been relatively rapid, but the second was gradual. Nevertheless, both discontinuities reflect significant changes in climate. Between the two, during the Oligocene and early Miocene, the isotopic variation appears greater than during the middle and late Miocene, after the second step. 
In contrast, the curve of ice sheet growth shows only one major discontinuity: the extremely sharp onset and initial growth of ice sheet volume from virtually zero to $40 \%$ of its present size, between about $20 \mathrm{~K}$ and $18 \mathrm{~K}$ in Fig. 6a. Otherwise, the curve shows only minor changes of slope, which we believe to be related to the progressive arrival of the grounding line at the margin. Possibly, therefore, we may attribute one of the two isotopic discontinuities to the continent-ice sheet system itself. The other is most probably of external origin (such as a sudden externally imposed change in sea-level temperature at the margin), to which the ice sheet responded.

We suggest that the $18-20 \mathrm{~K}$ discontinuity corresponds to the change at the Eocene-Oligocene boundary. The cause was extreme sensitivity of (East Antarctic) ice volume to sea-level temperature fall, compounded by the systematic formation of sea ice, in the Weddell Sea embayment in particular, amplifying the sea-level temperature drop. Before then, ice onshore was limited to isolated highlands, including some with occasional access to the oceans to provide the glacial sediments found in the western Ross Sea and Prydz Bay, and sparse ice-rafted debris on the Kerguelen Plateau (see Barrett, 1996, for a review).

It is necessary here to consider events at the Eocene-Oligocene boundary in more detail. The step in the isotope curve at the boundary coincides with a fundamental change in deep-water biota, indicating cooling (e.g. Benson, 1975), and with widespread erosion on the deep seafloor. Both are commonly associated with initiation of the modern thermohaline circulation driven by high-latitude cooling (e.g. Kennett and Shackleton, 1976; Johnson, 1985). At present, ambient water masses at the Antarctic margin are modified by two processes to create southern-origin bottom water: (1) by brine rejection from newly forming sea ice; and (2) by heat transfer to the very cold base of an ice shelf (particularly in the Weddell Sea: Foldvik and Gammelsrod, 1988). The second of these does not occur in the Arctic, and southern-origin bottom water is denser than the North Atlantic Deep Water, flowing beneath it where they are in contact (e.g. Mantyla and Reid, 1983). However, we cannot infer that both of these modifying processes were necessarily in action during the early Oligocene. A complete circumpolar path had not by then been established, and warm water from low latitudes could reach the Antarctic continental margin. For example, Oligocene calcareous nannofossils on Maud Rise and the Falkland Plateau were comparable, but were unlike assemblages from the southern and western Weddell Sea (Kennett and Barker, 1990). This suggests that an ACC-like circulation (hence a thermal isolation of the continent) was absent, but a clockwise Weddell gyre existed and water was modified in the southern Weddell Sea. However, to produce southern-origin bottom water at that time it would not have been necessary to invoke the second process (cooling beneath ice shelves) because the water being modified was itself warmer, and its erosional power may have been greater in the absence of the ACC and Polar Front as a barrier to northward flow (Barker, 1992). Thus, the state of ice sheet development that included the presence of an ice shelf in the southern Weddell Sea, while not ruled out for the Oligocene, is not required either.

The size of the early Oligocene ice sheet is uncertain. Provided the feedback effects (ocean cooling, sea-ice formation and albedo change, for example) were sufficiently strong, then the ice sheet could have grown beyond the $40 \%$ size of the steep section of Fig. 6a. An ice sheet $40 \%$ of its present size is equivalent to 0.3 to $0.4 \mathrm{ppm}$ of the step in the isotopic curve of Fig. 2b, leaving $0.6 \mathrm{ppm}$ to be explained by deep-ocean cooling, a temperature drop at the average deep-ocean site of up to $2.5^{\circ} \mathrm{C}$. The difficulty here is in being able to accept that, if such a fundamental change in the structure of the deep ocean as has been proposed took place at this time, the concept of 'the average deep-ocean site' is useful. A more detailed comparative study of deep-ocean temperature distribution will only be possible once the ambiguity between temperature and ice volume has been removed.

During the Oligocene, after the step, glacial ice reached the continental margin regularly, and IRD is more abundant at several sites (see Barrett, 1996). However, not all of East Antarctica need have been ice-covered, and the Oligocene and early Miocene included periods of relative warmth and low ice volume, reflected in the large isotopic variation in Fig. 2b. It is possible to see in Fig. $2 b$ also a general decrease in benthic $\delta^{18} \mathrm{O}$ through the Oligocene and early Miocene, reflecting a gradual warming or ice volume reduction. 
It is generally accepted that the middle Miocene step in the isotope curve (e.g. Flower and Kennett, 1994) and contemporaneous lowering of sea level (Haq et al., 1987; Fig. 2a) mark an intensification of Antarctic glaciation; the cold desert conditions that persist to this day along the Transantarctic Mts are considered to have begun at this time, and may have followed a warmer, wetter phase (Marchant et al., 1993). Major ice sheet expansion of middle Miocene age is inferred from drilling on the Weddell Sea margin of East Antarctica (Barker et al., 1988) and from a major hiatus within the glacial prograded wedge in Prydz Bay (Barker, 1995). The ice sheet appears to have grown so as to reach sea level virtually all around East Antarctica, but evidence for the level of West Antarctic glaciation is uncertain (e.g. De Santis et al., 1995). The reduced level of isotopic variation during the middle-late Miocene (Fig. 2b) is compatible with smaller fluctuations in ice volume, confined by the continental margin and generating only a small glacio-eustatic sea-level change.

Many (for example, Kennett, 1977; Barker and Burrell, 1982) have pointed to the present-day isolation of the Antarctic continent within a coldwater annulus, by the Antarctic Circumpolar Current (ACC) and associated Polar Front, as a potent contributor to continental cooling and glaciation. Numerical models of ocean circulation (e.g. Gill and Bryan, 1971; Cox, 1989; Oglesby, 1989; Mikolajewicz et al., 1993) show the dramatic reduction in meridional circulation that accompanies development of an ACC (although the effect on heat transport is less certain). In seeking an external, oceanographic cause for the middle Miocene intensification of Antarctic glaciation this is virtually the only candidate. And yet, the timing does not fit. The final barrier to complete deep-water circumpolar flow was either at the Shackleton Fracture Zone in Drake Passage, which cleared 23 million years ago (Barker and Burrell, 1977, 1982; see also Lawver et al., 1992), or perhaps along the North Scotia Ridge a little way to the east, which may have cleared shortly afterwards. In either case, there is a delay between this change in ocean circulation, tectonically controlled, and the renewed cooling and ice sheet growth exhibited in the isotopic record, which throws doubt on their causal relationship. At present, the misfit can only be attributed, speculatively, either to the existence of barriers in the Scotia Sea for much longer than hitherto considered possible, or to the existence of threshold effects in the circumpolar circulation, in which (for example) an effective barrier to meridional heat transfer does not develop until a certain level of zonal volume transport is achieved. Both of these options merit further investigation.

The third step in the isotope curve of Fig. 2b, beginning around 3 to $4 \mathrm{Ma}$, is associated with the growth of Northern Hemisphere ice sheets. It was accompanied by an increased amplitude of sea-level variation and followed by a change to a dominant 100,000 years cyclicity. The glacial cycle, which Huybrechts (1990) modelled and we discuss above, dominated the late Quaternary environment of the Antarctic ice sheet, even though the Antarctic contribution was mainly passive. It seems likely that, through this step, the Antarctic ice sheet became colder and less energetic (Barker, 1995). Consequently, its late Miocene and early Pliocene behaviour cannot be seen as similar to today's, differing only in a lesser external drive. The earlier ice sheet was warmer, and more energetic. It now seems unlikely that in the early Pliocene it was for long periods much smaller than today (Barker, 1995; Barrett, 1996), but the limits of its stability through this period are poorly known.

It is tempting to assess the likely average size of the ice sheet in times past, by comparing the model (Fig. 6) and the isotope curve (Fig. 2b), and thus to anticipate direct sampling by estimating when the initial arrival of the ice sheet at particular parts of the continental margin (e.g. Fig. 7) would have been. Thus, we may expect the eastern Weddell Sea and Prydz Bay margins to have been sensitive to ice stream flow either (initially) in the late Eocene, or earliest Oligocene (Fig. 7). The Weddell Sea margin may have been relatively insensitive thereafter, but Prydz Bay sediments should record also the broader advance of the ice sheet grounding line to the continental margin, whether before, after or during the middle Miocene step. Wilkes Land sediments will show a similar, overlapping sensitivity for East Antarctica (between 40 and $80 \%$ of present size), and the earliest signs of grounding line arrival there will define the limits of Oligocene and early Miocene ice volume. The onset of West Antarctic glaciation, most probably in the late-middle Miocene, will be 
best seen in the eastern Ross Sea. Antarctic Peninsula sediments from ODP Leg 178 drilling remain to be examined in detail, but our interpretation suggests a late Miocene development of glaciation, and a Pliocene transition from a regime in which sealevel change is internally generated to one where it is externally imposed.

\section{Conclusions}

We have described the characteristics of deposits of glacially derived, largely terrigenous sediment around the Antarctic continental margin and noted the record of glacial history they contain. We have shown how a numerical model of ice sheet development can be used to combine the glacial record from such deposits in different regions into a history of ice sheet development. This represents a strategy for extracting ice sheet history by direct sampling of margin sediments, which has been proposed through ANTOSTRAT and which the Ocean Drilling Program has begun to test, and may carry through. This strategy, its assumptions, conclusions and implications, have been explored in some detail. In addition, comparison of the numerical model of ice sheet sensitivity with oxygen isotopic proxy data leads us to speculative identification of the timing of ice sheet development and the causes of major changes. The elements of the sampling strategy, and results of the comparison, are listed below.

(1) Ice streams draining the Antarctic ice sheet, grounded to the continental shelf edge during glacial maxima, have deposited tills in a prograded wedge at the continental margin. The unstable component of slope deposits of the wedge has fed turbidity currents, the fine-grained sediment of which, in suspension and entrained in ambient bottom currents, has formed large hemipelagic drifts on the continental rise. Foreset and topset deposits of the prograded wedge, and drift sediments, contain complementary records of glacial history, that can be extracted by direct sampling.

(2) Numerical models of ice sheet development, that show the dependence of growth upon temperature and sea-level change, are now sufficiently detailed and reliable to form the basis of a method for combining data from glacial sediments in different regions of the Antarctic margin, to establish a history of Antarctic ice sheet development. Such a history is sorely needed, because of the essential ambiguity and apparent disagreement of estimates of ice sheet history derived from low-latitude proxy measurements. Direct sampling at only three or four regions of the continental margin (where seismic reflection cover is dense enough to map the glacial deposits) will be sufficient to establish the basic structure of ice sheet history. The Ocean Drilling Program undertook a drilling leg off the Antarctic Peninsula margin early in 1998 as a test of viability of the strategy, and is considering proposals for subsequent drilling in Prydz Bay, the Wilkes Land margin, and the eastern Ross and Weddell seas.

(3) Despite the general acceptability of recent numerical models, they neglect some features which may have affected ice sheet development. Those identified are the effects of sea-ice formation on sea-level temperature around the continent, uncertain parameterisation of precipitation, polar wander over the past 50 million years, the topography of the ice sheet base (examined in model sensitivity tests), and the existence of ice streams. We believe these effects are of limited importance, but would be interested in seeing them tested in future models.

(4) The particular model used here examined the modern glacial-interglacial cycle (of 'Milankovich' orbitally induced insolation change) but not past cycles, which were fundamentally different in the absence of large Northern Hemisphere ice sheets. We conclude, however, that the ice sheet would have responded to the glacial cycle in the past. In the early stages of ice sheet development its extent was extremely sensitive to temperature change. As it enlarged, its temperature sensitivity declined but it developed a volume sensitivity to sea-level change, that involved positive feedback. It is possible that a minimal, even zero sensitivity to Milankovich cyclicity occurred in the late Miocene or early Pliocene, if the ice sheet became insensitive to temperature change before the development of Northern Hemisphere glaciation.

(5) One important effect of the persistence of orbitally induced variation in ice sheet volume was an earlier initial arrival of the ice sheet grounding line at a particular margin than the 'average' or 'interglacial' temperature curve of Fig. 6 would indicate. 
(6) The published curve of oxygen isotopic variation in Atlantic benthic foraminifera through the Cenozoic shows three major steps, at the EoceneOligocene boundary, in the middle Miocene, and in the late Pliocene. This last is commonly associated with growth of Northern Hemisphere ice sheets, but the Antarctic ice sheet cooled as a result, and probably became less energetic and possibly more 'stable'.

(7) In contrast, the published curve of volume sensitivity of the model ice sheet to sea-level temperature shows only one discontinuity, related to the onset of ice sheet growth and its extreme sensitivity to temperature during initial growth (to $40 \%$ of present volume). We associate this single, internal discontinuity with the isotopic step at the EoceneOligocene boundary. Ice sheet sensitivity was enhanced by sea-ice formation in (at least) the Weddell Sea embayment, that was responsible for significant deep-ocean cooling and widespread erosion on the deep seafloor. The association is supported by the observed increase in abundance of ice-rafted debris around East Antarctica. Following this step, during the Oligocene and early Miocene, large fluctuations in isotopic composition could have resulted from ice sheet variation effectively unconstrained by the proximity of the Antarctic continental margin.

(8) The middle Miocene step in the isotopic curve is considered to have been externally imposed, in the absence of a second discontinuity in the model curve. The most likely origin is in the isolation of Antarctica caused by development of the ACC and Polar Front. However, a continuous circumpolar deep-water path may have been created as early as $23 \mathrm{Ma}$, or only a few million years later. For this to have been the cause of the middle Miocene discontinuity a delay would have been necessary, involving additional obstruction to deep-water flow within or around the Scotia Sea, or the need for a critical level of zonal flow to have developed before meridional heat exchange could be significantly attenuated. Following this second step, a reduction in amplitude of isotopic variation in the late Miocene and early Pliocene could have been caused by the constraining effects of the Antarctic continental margin on ice sheet volume change.

\section{Acknowledgements}

This exploration of the optimal way of using Antarctic margin sediments to help determine Antarctic glacial history was developed initially as a means of tying together submissions to the Ocean Drilling Program of separate regional ANTOSTRAT proposals. In its original form, therefore, it drew on the views of the ANTOSTRAT community as to the particular contribution of a region to an optimal drilling strategy and, subsequently, on the comments of individuals within the ODP structure. We are grateful for all of these comments, but this paper has now gone beyond those beginnings, and will, we hope, have value independently of the results of drilling, which will take time to emerge. We are grateful also for constructive comment from John Barron, Steve Eittreim, Tom Crowley and Jim Zachos.

\section{References}

Alley, R.B., Blankenship, D.D., Rooney, S.T., Bentley, C.R., 1989. Sedimentation beneath ice shelves: the view from Ice Stream B. Mar. Geol. 85, 101-120.

Alonso, B., Anderson, J.B., Diaz, J.I., Bartek, L.R., 1992. Pliocene-Pleistocene seismic stratigraphy of the Ross Sea: evidence for multiple ice sheet grounding episodes. Antarct. Res. Ser. 57, 93-103.

Barker, P.F., 1992. The sedimentary record of Antarctic climate change. Philos. Trans. R. Soc. London B 338, 259-267.

Barker, P.F., 1995. The proximal marine sediment record of Antarctic climate since the late Miocene. In: Cooper, A.K., Barker, P.F., Brancolini, G. (Eds.), Geology and Seismic Stratigraphy of the Antarctic Margin. Antarct. Res. Ser. 68, 25-57.

Barker, P.F., Burrell, J., 1977. The opening of Drake Passage. Mar. Geol. 25, 15-34.

Barker, P.F., Burrell, J., 1982. The influence on Southern Ocean circulation, sedimentation and climate of the opening of Drake Passage. In: Craddock, C. (Ed.), Antarctic Geoscience. Univ. Wisconsin Press, Madison, pp. 377-385.

Barker, P.F., Cooper, A.K., 1997. Geology and seismic stratigraphy of the Antarctic margin, Part 2. Antarct. Res. Ser. 71, 186 pp.

Barker, P.F., Kennett, J.P., Shipboard Scientific Party, 1988. Proceedings Ocean Drilling Program, Init. Rep. 113, College Station, TX, 785 pp.

Barker, P.F., Camerlenghi, A., Shipboard Scientific Party, 1999. Initial Reports of the Deep Sea Drilling Project, Leg 178, College Station, TX.

Barrett, P.J., 1989. Antarctic Cenozoic History from the CIROS-I 
Drillhole, McMurdo Sound. DSIR, Wellington, Bull. 245, 251 pp.

Barrett, P.J., 1996. Antarctic palaeoenvironment through Cenozoic times - a review. Terra Antart. 3, 103-119.

Barron, J., Larsen, B., Shipboard Scientific Party, 1989. Proceedings Ocean Drilling Program, Init. Rep. 119, College Station, TX, 942 pp.

Bartek, L.R., Vail, P.R., Anderson, J.B., Emmet, P.A., Wu, S., 1991. The effect of Cenozoic ice sheet fluctuations in Antarctica on the stratigraphic signature of the Neogene. J. Geophys. Res. 96, 6753-6778.

Bell, R.E., Blankenship, D.D., Finn, C.A., Morse, D.L., Scambos, T.A., Brozena, J.M., Hodge, S.M., 1998. Influence of subglacial geology on the onset of a West Antarctic ice stream from aerogeophysical observations. Nature 394, 58-62.

Benson, R.H., 1975. The origin of the psychrosphere as recorded in changes in deep-sea ostracode assemblages. Lethaia 8, 6983.

Bentley, C.R., 1984. Some aspects of the cryosphere and its role in climatic change. AGU Geophys. Monogr. 29, 207-220.

Berggren, W.A., Kent, D.V., Flynn, J.J., Van Couvering, J.A., 1985. Cenozoic geochronology. Bull. Geol. Soc. Am. 96, 1407-1418.

Berggren, W.A., Kent, D.V., Swisher, C.C. III, Aubry, M.-P., 1995. A revised Cenozoic geochronology and chronostratigraphy. In: Berggren, W.A., Kent, D.V., Aubry, M.-P., Hardenbol, J. (Eds.), Geochronology, Time Scales and Global Stratigraphic Correlation. Soc. Sediment. Geol. Spec. Publ. 54, 129-212.

Broecker, W.S., Peng, T.-H., 1982. Tracers in the Sea. Eldigio Press, New York, 689 pp.

Browning, J.V., Miller, K.G., Pak 1996, D.L., 1996. Global implications of lower to middle Eocene sequence boundaries on the New Jersey coastal plain: the icehouse cometh. Geology 24, 639-642.

Camerlenghi, A., Rebesco, M., Pudsey, C.J., 1997. High-resolution terrigenous sedimentary record of a sediment drift on the Antarctic Peninsula Pacific margin (initial results of the SEDANO program). In: Ricci, C.A. (Ed.), The Antarctic Region: Geological Evolution and Processes. Terra Antartica Publication, Siena, pp. 705-710.

Cande, S.C., Kent, D.V., 1992. A new geomagnetic polarity time scale for the Late Cretaceous and Cenozoic. J. Geophys. Res. 97, 13917-13952.

Cooper, A.K., Barrett, P.J., Hinz, K., Traube, V., Leitchenkov, G., Stagg, H.M.J., 1991a. Cenozoic prograding sequences of the Antarctic continental margin: a record of glacio-eustatic and tectonic events. Mar. Geol. 102, 175-213.

Cooper, A.K., Stagg, H.M.J., Geist, E., 1991b. Seismic stratigraphy and structure of Prydz Bay, Antarctica: implications from Leg 119 drilling. Proc. ODP, Sci. Results 119, 5-26.

Cooper, A.K., Barker, P.F., Webb, P.-N., Brancolini, G., 1994. The Antarctic continental margin - the Cenozoic record of glaciation, palaeoenvironments and sea-level change. Terra Antart. 1, 236-480.

Cooper, A.K., Barker, P.F., Brancolini, G., 1995. Geology and seismic stratigraphy of the Antarctic margin. Antarct. Res. Ser. 68, $301 \mathrm{pp}$, Atlas, CD-ROMs.

Cox, M.D., 1989. An idealised model of the world ocean, part 1. The global-scale water masses. J. Phys. Oceanogr. 13, $1093-$ 1104.

Denton, G.H., Sugden, D.E., Marchant, D.R., Hall, B.L., Wilch, T.I., 1993. East Antarctic ice sheet sensitivity to Pliocene climate change from a Dry Valleys perspective. Geogr. Ann. 75A, 155-204.

De Santis, L., Anderson, J.B., Brancolini, G., Zayatz, I., 1995. Seismic record of late Oligocene through Miocene glaciation on the central and eastern continental shelf of the Ross Sea. In: Cooper, A.K., Barker, P.F., Brancolini, G. (Eds.), Geology and Seismic Stratigraphy of the Antarctic Margin. Antarct. Res. Ser. 68, 235-260.

Diester-Haas, L., Zahn, R., 1996. Eocene-Oligocene transition in the Southern Ocean: history of water mass circulation and biological productivity. Geology 24, 163-166.

DiVenere, V.J., Kent, D.V., Dalziel, I.W.D., 1994. Mid-Cretaceous paleomagnetic results from Marie Byrd Land, West Antarctica: a test of post-100 Ma relative motion between East and West Antarctica. J. Geophys. Res. 99, 15115-15139.

Drewry, D.J., 1983. Antarctica: Glaciological and Geophysical Folio. Scott Polar Research Institute, Cambridge (England) 9 sheets.

Drewry, D.J., Morris, E.M., 1992. The response of large ice sheets to climate change. Philos. Trans. R. Soc. London B 338, 235-242.

Ehrmann, W.U., Mackensen, A., 1992. Sedimentological evidence for the formation of an East Antarctic ice sheet in Eocene/Oligocene time. Palaeogeogr., Palaeoclimatol., Palaeoecol. 93, 85-112.

Eittreim, S.L., Cooper, A.K., Wannesson, J., 1995. Seismic stratigraphic evidence of ice-sheet advances on the Wilkes Land margin of Antarctica. Sediment. Geol. 96, 131-156.

Escutia, C., Eittreim, S.L., Cooper, A.K., 1997. Cenozoic sedimentation on the Wilkes Land continental rise, Antarctica. In: Ricci, C.A. (Ed.), The Antarctic Region: Geological Evolution and Processes. Terra Antartica Publication, Siena, pp. 791795.

Fastook, J.L., 1984. West Antarctica, the sea-level-controlled marine instability: past and future. AGU Geophys. Monogr. 29, 275-287.

Fitzgerald, P.G., 1992. The Transantarctic Mountains of Southern Victoria Land: the application of apatite fission track analysis to a rift shoulder uplift. Tectonics 11, 634-662.

Fitzgerald, P.G., 1994. Thermochronologic constraints on postPaleozoic tectonic evolution of the central Transantarctic Mountains, Antarctica. Tectonics 13, 818-836.

Flower, B.P., Kennett, J.P., 1994. The middle Miocene climatic transition: East Antarctic ice sheet development, deep ocean circulation and global carbon cycling. Palaeogeogr., Palaeoclimatol., Palaeoecol. 108, 537-555.

Foldvik, A., Gammelsrod, T., 1988. Notes on Southern Ocean hydrography, sea-ice and bottom-water formation. Palaeogeogr., Palaeoclimatol., Palaeoecol. 67, 3-17.

Fortuin, J.P.F., Oerlemans, J., 1990. Parameterisation of the an- 
nual surface temperature and mass balance of Antarctica. Ann. Glaciol. 14, 78-84.

Gill, A.E., Bryan, K., 1971. Effects of geometry on a threedimensional southern-hemisphere ocean model. Deep-Sea Res. $18,685-721$.

Giovinetto, M.B., Waters, N.M., Bentley, C.R., 1990. Dependence of Antarctic surface mass balance on temperature, elevation, and distance to open ocean. J. Geophys. Res. 95, 3517-3531.

Hannah, M.J., 1994. Eocene dinoflagellates from the CIROS-1 drill hole, McMurdo Sound. Terra Antart. 1, 371-372.

Haq, B.U., Hardenbol, J., Vail, P.R., 1987. Chronology of fluctuating sea levels since the Triassic. Science 235, 1156-1167.

Haq, B.U., Hardenbol, J., Vail, P.R., 1988. Mesozoic and Cenozoic chronostratigraphy and eustatic cycles. In: Wilgus, C.K., Hastings, B.S., Kendall, C.G.St.C., Posamentier, H.W., Ross, C.A., Van Wagoner, C. (Eds.), Sea-Level Changes: an Integrated Approach. Soc. Econ. Paleontol. Mineral. Spec. Publ. 42, 71-108.

Harwood, D.M., Webb, P.-N., 1998. Glacial transport of diatoms in the Antarctic Sirius Group: Pliocene refrigerator. GSA Today 8 (4), 1-8.

Hayes, D.E., Frakes, L.A., Shipboard Party, 1975. Deep Sea Drilling Project, Init. Rep. 28, Washington, DC, 1017 pp.

Huybrechts, P., 1990. A 3-D model for the Antarctic ice sheet: a sensitivity study on the glacial-interglacial contrast. Climate Dyn. 5, 79-92.

Huybrechts, P., 1992. The Antarctic ice sheet and environmental change: a three-dimensional modelling study. [Ph.D. thesis, Vrije Universiteit Brussel] Ber. Polarforsch. 99, 241 pp.

Huybrechts, P., 1993. Glaciological modelling of the Late Cenozoic East Antarctic ice sheet: stability or dynamism. Geogr. Ann. 75A, 221-238.

Huybrechts, P., T'siobbel, S., 1997. A three-dimensional climate/ice-sheet model applied to the Last Glacial Maximum. Ann. Glaciol. 25, 333-339.

Johnson, D.A., 1985. Abyssal teleconnections II. Initiation of Antarctic Bottom Water flow in the southwestern Atlantic. In: Hsu, K.J., Weissert, H.J. (Eds.), South Atlantic Paleoceanography. Cambridge Univ. Press, Cambridge, pp. 243-281.

Kennett, J.P., 1977. Cenozoic evolution of Antarctic glaciation, the circum-Antarctic ocean, and their impact on global paleoceanography. J. Geophys. Res. 82, 3843-3860.

Kennett, J.P., Barker, P.F., 1990. Latest Cretaceous to Cenozoic climate and oceanographic developments in the Weddell Sea, Antarctica: an ocean-drilling perspective. Proc. ODP, Sci. Results 113, 937-960.

Kennett, J.P., Shackleton, N.J., 1976. Oxygen isotopic evidence for the development of the psychrosphere 38 myr ago. Nature 260, 513-515.

King, J.C., Turner, J., 1997. Antarctic Meteorology and Climatology. Cambridge Univ. Press, Cambridge, 409 pp.

Kominz, M.A., Miller, K.G., Browning, J.V., 1998. Long-term and short-term global Cenozoic sea-level estimates. Geology 26, 311-314.

Kuvaas, B., Kristoffersen, Y., 1991. The Crary Fan: a trough- mouth fan on the Weddell Sea continental margin, Antarctica. Mar. Geol. 97, 345-362.

Kuvaas, B., Leitchenkov, G., 1992. Glaciomarine turbidite and current-controlled deposits in Prydz Bay, Antarctica. Mar. Geol. 108, 365-381.

Larter, R.D., Barker, P.F., 1989. Seismic stratigraphy of the Antarctic Peninsula Pacific margin: a record of PliocenePleistocene ice volume and paleoclimate. Geology 17, 731734.

Larter, R.D., Barker, P.F., 1991. Neogene interaction of tectonic and glacial processes at the Pacific margin of the Antarctic Peninsula. In: Macdonald, D.I.M. (Ed.), Sedimentation, Tectonics and Eustasy. Int. Assoc. Sedimentol. Spec. Publ. 12, 165-186.

Lawver, L.A., Gahagan, L.M., Coffin, M.F., 1992. The development of paleoseaways around Antarctica. Antarct. Res. Ser. $56,7-30$.

Leitchenkov, G., Stagg, H.M.J., Gandjukhin, J., Cooper, A.K., Tanahashi, M., O’Brien, P., 1994. Cenozoic seismic stratigraphy of Prydz Bay (Antarctica). In: Cooper, A.K., Barker, P.F., Webb, P.-N., Brancolini, G. (Eds.), The Antarctic Continental Margin - the Cenozoic Record of Glaciation, Palaeoenvironments and Sea-Level Change. Terra Antart. 1 (2), 395-398.

Mantyla, A.W., Reid, J.L., 1983. Abyssal characteristics of the world ocean waters. Deep-Sea Res. 30, 805-833.

Marchant, D.R., Denton, G.H., Sugden, D.E., Swisher III, C.C., 1993. Miocene glacial stratigraphy and landscape evolution of the western Asgard Range, Antarctica. Geogr. Ann. 75A, 303-330.

Matthews, R.K., Poore, R.Z., 1980. Tertiary $\delta^{18} \mathrm{O}$ record and glacio-eustatic sea-level fluctuations. Geology 8, 501-504.

Miall, A.D., 1991. Stratigraphic sequences and their chronostratigraphic correlation. J. Sediment. Petrol. 61, 497-505.

Mikolajewicz, U., Maier-Reimer, E., Crowley, T.J., Kim, K.-Y., 1993. Effects of Drake and Panamanian gateways on the circulation of an ocean model. Paleoceanography 8, 409-426.

Miller, K.G., Fairbanks, R.G., Mountain, G.S., 1987. Tertiary oxygen isotope synthesis, sea-level history and continental margin erosion. Paleoceanography 2, 1-19.

Miller, K.G., Mountain, G.S., Leg 150 Shipboard Party and Members of the New Jersey Coastal Plain Drilling Project, 1996. Drilling and dating New Jersey Oligocene-Miocene sequences: ice volume, global sea level, and Exxon records. Science 271, 1092-1095.

Oglesby, R.J., 1989. A GCM study of Antarctic glaciation. Climate Dyn. 3, 135-156.

Oglesby, R.J., 1991. Joining Australia to Antarctica: GCM implications for the Cenozoic record of Antarctic glaciation. Climate Dyn. 6, 13-22.

Paterson, W.S.B., 1994. The Physics of Glaciers (3rd ed.). Pergamon Press, Oxford, 480 pp.

Pisias, N.G., Shackleton, N.J., Hall, M.A., 1985. Stable isotope and calcium carbonate records from hydraulic piston-cored Hole 574A: high-resolution records from the middle Miocene. Init. Rep. DSDP 85, 735-748.

Rebesco, M., Larter, R.D., Camerlenghi, A., Barker, P.F., 1996. 
Giant sediment drifts on the continental rise of the Antarctic Peninsula. Geo-Mar. Lett. 16, 65-75.

Rebesco, M., Larter, R.D., Barker, P.F., Camerlenghi, A., Vanneste, L.E., 1997. The history of sedimentation on the continental rise west of the Antarctic Peninsula. In: Barker, P.F., Cooper, A.K. (Eds.), Geology and Seismic Stratigraphy of the Antarctic Margin, Part 2. Antarct. Res. Ser. 71, 29-49.

Sahagian, D.L., Watts, A.B., 1991. Introduction to the Special Section on measurement, causes and consequences of longterm sea level changes. J. Geophys. Res. 96, 6585-6589.

Schrag, D.P., Hampt, G., Murray, D.W., 1997. Oxygen isotopic composition of interstitial waters from Leg 154: determination of the temperature and isotopic composition of the glacial ocean. Proc. ODP, Sci. Results 154, 201-206.

Shackleton, N.J., Hall, M.A., Pate, D., 1995. Pliocene stable isotope stratigraphy of Site 846. Proc. ODP, Sci. Results 138, 337-355.

Showstack, R., 1997. Radarsat survey provides accurate map of Antarctica. EOS 78, 461-462.

Stroeven, A.P., Burckle, L.H., Kleman, J., Prentice, M.L., 1998. Atmospheric transport of diatoms in the Antarctic Sirius Group: Pliocene deep freeze. GSA Today 8 (4), 1-5.

Ten Brink, U.S., Cooper, A.K., 1992. Modelling the bathymetry of the Antarctic continental shelf. In: Yoshida, Y., Kaminuma, K., Shiraishi, K. (Eds.), Recent Progress in Antarctic Earth
Sciences. TERRAPUB, Tokyo, pp. 763-771.

Thiede, J., Myhre, A.M., 1996. The paleoceanographic history of the North Atlantic-Arctic gateways: synthesis of the Leg 151 drilling results. Proc. ODP, Sci. Results 151, 645-658.

Tiedemann, R., Sarnthein, M., Shackleton, N.J., 1994. Astronomic timescale for the Pliocene Atlantic $\delta^{18} \mathrm{O}$ and dust flux records of Ocean Drilling Program Site 659. Paleoceanography 9, 619-638.

Webb, P.-N., Harwood, D.M., 1991. Late Cenozoic glacial history of the Ross Sea embayment, Antarctica. Quat. Sci. Rev. 10, 215-223.

Webb, P.-N., Harwood, D.M., Mabin, M.C.G., McKelvey, B.C., 1996. A marine and terrestrial Sirius Group succession, middle Beardmore Glacier-Queen Alexandra Range, Transantarctic Mountains, Antarctica. Mar. Micropalaeontol. 27, 273-298.

Wise Jr., S.W., Breza, J.R., Harwood, D.M., Zachos, J.C., 1992. Paleogene glacial history of Antarctica in light of Leg 120 drilling results. Proc. ODP, Sci. Results 120, 1001-1030.

Zachos, J.C., Quinn, T.M., Salamy, K.A., 1996. High-resolution $\left(10^{4}\right.$ years $)$ deep-sea foraminiferal stable isotope records of the Eocene-Oligocene climate transition. Paleoceanography 11, 251-266.

Zachos, J.C., Flower, B.P., Paul, H., 1997. Orbitally paced climate oscillations across the Oligocene/Miocene boundary. Nature $388,567-570$. 